\title{
Medicare Financing and Redistribution in British Columbia, 1992 and 2002
}

\author{
Financement et redistribution du régime \\ d'assurance-maladie en Colombie-Britannique, \\ 1992 et 2002
}

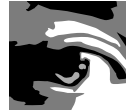

by KIMBERLYN MCGRAIL, MPH, PHD

Post-doctoral Fellow

Statistics Canada and the Centre for Health Economics and Policy Analysis, McMaster University, Hamilton, $O N$

Centre for Health Services and Policy Research, University of British Columbia

Vancouver, BC
\end{abstract}

\begin{abstract}
Equity in healthcare in British Columbia is defined as the provision of services based on need rather than ability to pay and a separation of contributions to financing from the use of services. Physician and hospital services in Canada are financed mainly through general tax revenues, and there is a perception that this financing is progressive. This paper uses Gini coefficients, concentration indexes and Kakwani indexes of progressivity to assess the progressivity of medicare financing in British Columbia in 1992 and 2002. It also measures the overall redistributive effect of medicare services, considering both contributions to financing and use of hospital and physician services. The conclusion is that medicare does redistribute across income groups, but
\end{abstract}


this redistribution is the result solely of the positive correlation between health status and income; financing is nearly proportionate across income groups, but use is higher among lower-income groups. Informed public debate requires a better understanding of these concepts of equity.

\section{Résumé}

Léquité dans les soins de santé en Colombie-Britannique est définie comme étant la prestation de services en fonction du besoin plutôt quen fonction de la capacité de payer, et une séparation des contributions au financement et de l'utilisation des services. Les services fournis par les médecins et les hôpitaux au Canada sont financés principalement par les recettes fiscales générales, et beaucoup croient que ce financement est progressif. Cet article utilise les coefficients de Gini, les indices de concentration et les indices de progressivité de Kakwani pour évaluer la progressivité du financement de l'assurance-maladie en Colombie-Britannique en 1992 et en 2002. Il mesure également l'effet de redistribution général des services d'assurance-maladie, en tenant compte à la fois des contributions au financement et de l'utilisation des services fournis par les hôpitaux et les médecins. On en vient à la conclusion que l'assurance-maladie est redistribuée entre les différents groupes de revenus, mais que cette redistribution est uniquement le résultat de la corrélation positive entre létat de santé et le revenu; le financement est presque proportionnel entre les groupes de revenus, mais l'utilisation est plus élevée chez les groupes à plus faible revenu. Un débat public éclairé exige une meilleure compréhension de ces concepts d'équité.

He HeAlThCARE SYSTEM IN CANADA IS OfTEN DESCRIBED AS A Key
national treasure, an integral part of the country's identity. The ongoing pres-
ence of healthcare in discussions and debates reflects not only the importance of the system to the general public, but also the fact that healthcare in Canada is largely a public enterprise. The majority of healthcare services are publicly funded, the private insurance market is absent in the key areas of hospital and physician services, and provincial governments are the primary payers.

A review of federal and provincial (British Columbia) legislation and major policy documents identified three related, but distinct, principles of equity for the healthcare system (McGrail 2006). The primary equity principle in healthcare in British Columbia is the provision of services (at least hospital and physician services) based on need rather than ability to pay. The second is the financing of those services from tax revenues, effectively separating financial contributions to the healthcare system from use of physician and hospital services. These values may not be immutable, but 
they have been clear and consistent over several decades. More contentious is the third principle of equity: financing hospital and physician services through progressive taxation. This principle emerges only in the report of the Romanow Commission (2002), but seems to have longer-standing resonance with the public (Mendelsohn 2004).

Publicly financed healthcare systems are redistributive, taking financing from the whole of the population and providing healthcare services to the individuals who need them. The extent of the total redistribution depends on two separate policy choices related to the principles of equity in financing. One choice is the desired redistribution from healthy to sick. The stronger the separation between contributions to financing and use of healthcare services, the greater will be this redistribution.

The second policy choice is the desired redistribution among income groups, determined by the relative mix of sources of finance. Generally speaking, there are five major potential sources of funds to support any healthcare system: direct taxation (e.g., income taxes), indirect taxation (e.g., consumption taxes), social insurance, private insurance and out-of-pocket payments (Wagstaff et al. 1999).

Redistribution among income groups is determined by the total progressivity or regressivity of financial contributions to the healthcare system. Progressive financing means that the proportion of taxes that are paid increases with income, with the result that the distribution of income is more equal after healthcare financing. Proportionate systems claim equal percentage shares of income from all income groups, leaving the distribution of income unchanged. In regressive systems, lower-income groups pay a higher proportionate share of income, resulting in a more unequal distribution of income after healthcare financing. (Even in a regressive system, higher-income groups may contribute more in total dollars to healthcare financing. The key is not the total amount of money contributed, but the proportion of total income that those contributions represent.)

When there is public discussion about financing medicare services in Canada, the tendency is to think of income taxes, which are progressive, as being the main source of that financing. A good example of this thinking comes from the Romanow Commission's report, which relied heavily on the work of a "Citizens' Dialogue" to inform its positions on the public's values and the policy changes within healthcare that the public thought were most palatable (Maxwell et al. 2002). In each of 12 sessions across the country, a small group of individuals was invited to join a day-long discussion and debate about the healthcare system, its current problems and potential solutions. The day both started and ended with a survey about preferred policy options in an attempt to assess both the opinions that people hold and how those opinions changed after informed debate. The idea was to go "deeper" into the issues than is possible with standard polling techniques.

The results of the Citizens' Dialogue were described as clear and consistent across the country: "... [A]t the end of the day, citizens came to the conclusion that taxes are consistent with their notion of solidarity - that health care is a public good to be 
financed by public means" (Maxwell et al. 2002: 45). In fact, the general preference was for earmarked taxes as a means of improving accountability for healthcare spending.

A closer reading of the Dialogue materials suggests that the word "taxes" is in fact treated as synonymous with "income taxes." For example, the preparatory material for the focus groups says, in part,"This would mean that on average personal income taxes would be 12 percent higher than in 1999" (Maxwell et al. 2002: 99; emphasis added). In addition, the final report from the Romanow Commission referred to a continuing commitment to funding healthcare through "progressive taxation" (Romanow 2002: 31).

The objectives of this paper are to assess the progressivity of financing hospital and physician services in British Columbia in 1992 and 2002, as well as the overall redistributive effect of those sectors, considering the use of services as well as financing. This work follows methods used in studies in the tax literature that assess the effects of government policies on income distribution (Vermaeten et al. 1995; Kesselman and Cheung 2004; Dyck 2005), and in particular the work of Mustard et al. (1998), which focused specifically on the healthcare system. The hypotheses are that the progressivity of the tax system decreased in British Columbia between 1992 and 2002 and that the total redistributive effect, combining financing and healthcare services use, also decreased between 1992 and 2002.

The next section describes the data sources and construction of variables used in the analyses. The following section then describes the analytic techniques used to assess progressivity and redistributive effect. This is followed by results, and then discussion and conclusions.

\section{Data Sources and Variables}

The majority of financing for physician and hospital services in Canada comes from general government revenues (CIHI 2005). Because this paper looks at financing physician and hospital services, the analyses do not depend on estimating the cost or distribution of private insurance covering such services as pharmaceuticals and dentistry.

The focus here is on the income and tax concepts shown in Figure 1. In addition, following Mustard et al. (1998), the dollar value of hospital and physician services are treated as a "transfer" to the household using them. In other words, though the value of healthcare services is not "income," for purposes of these analyses it is treated in the same way as an income transfer as a way of attributing that benefit back to each household. Analyses are conducted at the household level. Ethics approval was granted by the UBC Behavioural Research Ethics Board. Access to person-specific but nonidentifying information on healthcare services utilization was granted through the $\mathrm{BC}$ Linked Health database (Chamberlayne et al. 1998; British Columbia Ministry of Health and Centre for Health Services and Policy Research, UBC 1996). 
FIGURE 1. Creation of the analytic file

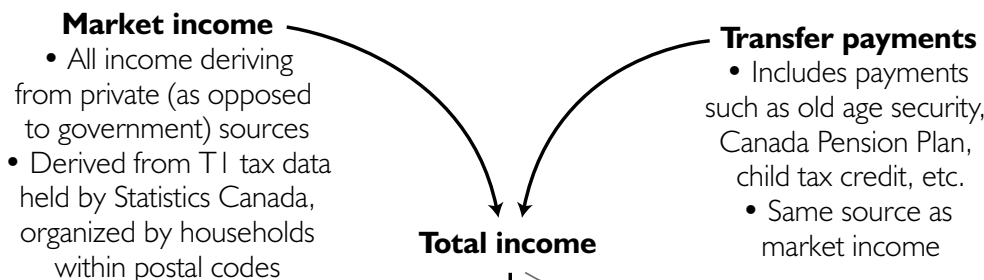
within postal codes

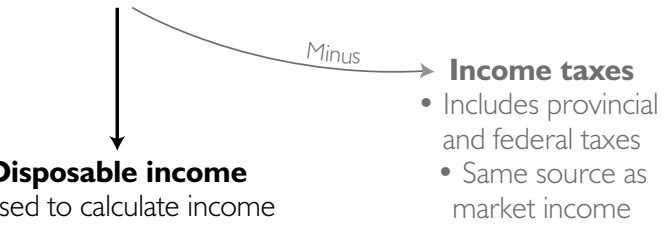

- Used to calculate income per person within postal codes

- Then rank postal codes by income and create I,000 income groups

Use of hospitals and physician services

- Sum of individual-level physician and hospital expenditures during each year

- Hospital costing based on Resource Intensity Weights

- Derived from BC Linked Health Data set
- Same source as market income

Consumption taxes

- Estimates based on

broad income groupings

- Statistics Canada

Social Policy Simulation

Database and Model

Consumable income

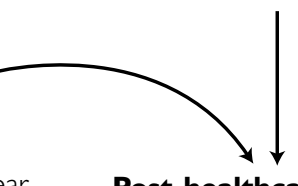

Post-healthcare income

Medical services premium

- Premium paid by all

$\mathrm{BC}$ residents eligible for

health insurance coverage

- Amount of payment based

on income and family size

- Total amount paid assigned using family-level subsidy information from healthcare use file

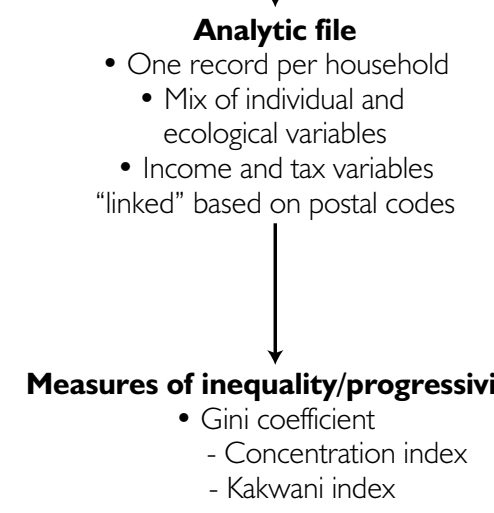

Income, income taxes and government transfers

The income and income tax variables used here are based on a custom tabulation of 1992 and 2002 tax filer data held at Statistics Canada (McGrail 2006). Data can be 
released from Statistics only in highly aggregated form. User-specified analyses conducted within Statistics Canada started with a known number or amount of individuals, households, income and tax and transfer payments within postal codes. For each postal code, the Statistics Canada analyst calculated disposable income per equivalized person, ranked the postal codes by this income and created 1,000 income bands, each containing (approximately) 1,400 families and 3,700 individuals. Equivalization is a means of ensuring comparability, with the assumption that the objective is to compare living standards (Ebert 1997, 1999). For example, a couple requires less than two times the income of a single person to achieve the same standard of living. Incomes per equivalized person were derived using the OECD modified scale, counting the first adult as "1," each subsequent person aged 14 and over as " 0.5 " and each child under age 14 as "0.3" (van Doorslaer et al. 2004a,b). This approach was chosen, first, because it allowed the creation of a large number of income bands and, second, because while the resulting variables are ecological, the heterogeneity of these variables within postal codes will be smaller than the heterogeneity within Statistics Canada dissemination areas, which are the unit used to create the commonly used income quintiles and deciles (Wilkins 2001).

\section{Estimating consumption taxes and medical services premiums}

In Canada, the majority of consumption taxes are collected in the form of provincial sales taxes and the federal Goods and Services Tax (GST), but other sources include excise and import taxes at the federal level, and alcohol, liquor and gasoline taxes at the provincial level (Statistics Canada 2004b).

Statistics Canada has developed the Social Policy Simulation Database and Model (Statistics Canada 2003), available free of charge through the Data Liberation Initiative (Statistics Canada 2004a). This software allows the estimation of province-specific consumption taxes and includes a table option that organizes output by income group. The unadjusted average disposable income per person in the income data set described above was used to "link" the per household consumption tax estimates to those data. (See Table 4 in the Appendix at http://www.longwoods.com/ product.php?productid $=18863 \&$ cat $=488$ )

British Columbia is one of two provinces that, in 1992 and 2002, charged "insurance premiums" to patients as a requirement for registration with the province for medical services coverage. Premiums are set based on family size, with subsidies available for low-income families. Premiums are allocated to families using subsidy information available on the physician services file (McGrail 2006). (See Table 5 and Table 6 in the online Appendix.) 


\section{Adding in hospital and physician expenditures}

Administrative data from the BC Linked Health Database (BCLHD) provided information on individual-level use of hospital and physician services. These data were aggregated within each year of analysis, first to the individual level and then to families, based on a family-grouping variable available in that data set. Fees paid are included as part of the physician file. Hospital costs were estimated using Resource Intensity Weights and Day Resource Intensity Weights applied to acute inpatient and surgical day care separations, respectively, following procedures used by the BC Ministry of Health (S. Lee, personal communication 2002). Family postal codes were used to "link" utilization information to the 1,000 income bands described above.

\section{Analysis}

The distribution of income within a population can be depicted with a Lorenz curve. Ranking families in British Columbia in 2002 from lowest to highest disposable income using the variable described above, and then cumulating the population and their income (Figure 2, solid line), shows that the lowest-income $60 \%$ of the population earn about $45 \%$ of total income. If, instead, everyone earned the same income, the Lorenz curve would be the straight diagonal line shown in the figure, referred to as the line of equality. Gini coefficients summarize the amount of inequality in the population by calculating the distance between the Lorenz curve and the line of equality and then dividing by the total area under the line of equality. A Gini coefficient of 0 occurs when the Lorenz curve and the line of equality are the same, meaning there is no inequality in the distribution of income. A Gini coefficient of 1 indicates that all of the income is held by one person - perfect inequality.

The same idea can be applied to distributions other than income, such as payment of taxes. In these cases, there are concentration curves and concentration indexes (with the different names reflecting only that "Lorenz curve" and "Gini coefficient" are reserved for income distributions). The dotted line on Figure 2 shows payment of federal and provincial income taxes in British Columbia in 2002, and indicates that the lowest-income $60 \%$ of the population pay about $35 \%$ of all income taxes.

If the tax system is proportionate, meaning that all income levels face the same tax rate, then the Lorenz curve for pre-tax income and the concentration curve for tax payments would lie on top of each other; the tax has an impact on the amount of income available to each household, but no impact on the relative distribution of that income. Taxes can also be progressive (or regressive), meaning that the income distribution is more equal (or less equal) after the payment of taxes. As proposed by Kakwani (1977), the overall progressivity of a tax is the numeric difference between the concentration index of the tax and the Gini coefficient of the pre-tax income distribution $(\mathrm{K}=\mathrm{C}-\mathrm{G})$. If the concentration curve for the tax lies below the Lorenz 
curve, farther from the line of equality, as it does in Figure 2, C would be larger than $\mathrm{G}$, which makes $\mathrm{K}$ positive, indicating a progressive tax. If instead the concentration curve for the tax lies between the Lorenz for income and the line of equality, $\mathrm{G}$ would be larger than $\mathrm{C}$ and $\mathrm{K}$ would be negative - indicating a regressive tax.

FIGURE 2. Lorenz curve of pre-tax income and concentration curve for tax payments, British Columbia, 2002

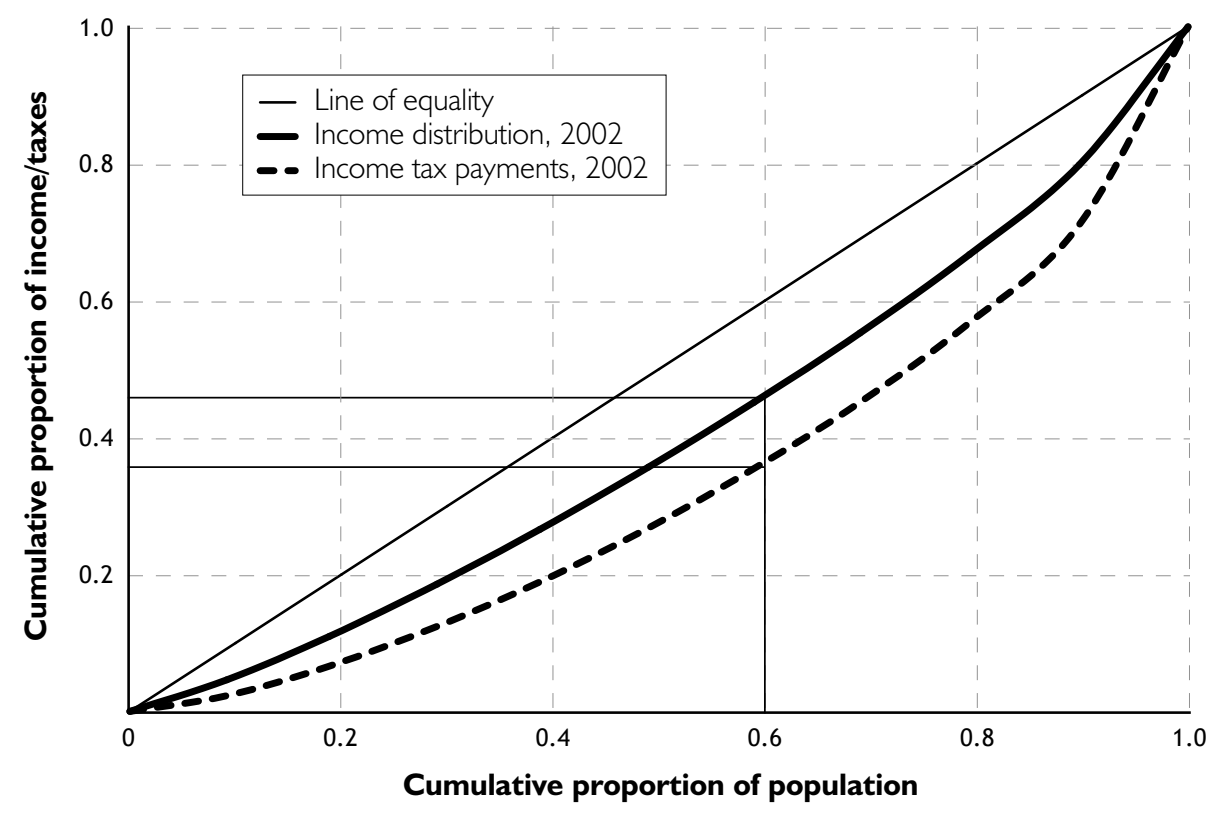

Finally, Kakwani (1977) also showed that the total Gini coefficient for income is a weighted average of the Gini coefficients of each of the contributing sources of income. This idea has been applied to healthcare financing, where the overall progressivity of financing is a weighted average of the progressivity of all of the input components (Wagstaff et al. 1999); the same is done here.

The analysis thus consists of calculations of Gini coefficients and concentration indexes for the income, transfer and tax concepts in the data provided by Statistics Canada and for the healthcare services utilization data. These are calculated using linear regression (Jenkins 1988; Kakwani et al. 1997). Kakwani indexes are calculated by simply subtracting the Gini coefficient of the distribution of total income from the concentration index for each tax, transfer and healthcare utilization measure. 


\section{Results}

\section{Overall distribution of healthcare finance}

A large portion of general government revenue derives from taxes, both direct (income) and indirect (consumption and other) (see Table 1 in the online Appendix). About half of federal government revenues derive from personal income taxes, which means that we can estimate the distribution of payment by income of about half of British Columbia government revenues (from Table 1, 18.4\% from personal income taxes $+21.2 \%$ from consumption taxes $+3.2 \%$ from MSP premiums $+0.5(9.2 \%$ from general purpose transfers from the federal government $+2.4 \%$ from special-purpose transfers from the federal government) $=48.6 \%$ in 2002).

\section{Distribution of income and progressivity of tax payments}

By any income measure - market income, total income, disposable income or consumable income - inequality as measured by Gini coefficients increased between 1992 and 2002 (Table 2). The Gini coefficients reported here are smaller (suggesting a more equal income distribution) than reported elsewhere because of the ecological nature of the income variables. The patterns of change, however, are consistent with other analyses (Frenette et al. 2004; McGrail 2006).

Concentration indexes for transfers are negative because these are payments that are provided disproportionately to lower-income groups - they have the effect of decreasing income inequality. The concentration and Kakwani indexes for income taxes also increased in size between 1992 and 2002, meaning that income taxes were more progressive in 2002. (In fact, income taxes became more progressive in the early part of the 1990s and retained that progressivity through substantial tax cuts in 2000 and 2001 [McGrail 2006].) Table 1, however, also shows that provincial income taxes declined as a share of government revenue between 1992 and 2002 from a high of $23 \%$ to $18.5 \%$ of the total.

The payment of consumption taxes was more highly concentrated in higher-income groups in 2002 compared to 1992, resulting in a slight decline in the regressivity of those taxes. At the same time, consumption taxes grew in importance as a source of general government revenue (Table 1 in the online Appendix). The BC premium payments were also more concentrated in higher-income groups in 2002 because of a policy change that increased subsidies available for lower-income families (Tables 5 and 6 in the online Appendix). Nevertheless, these premiums were similarly and substantially regressive in both years.

Finally, the use of hospital and physician services, like transfer payments, is more highly concentrated in lower-income groups, and the impact on income distribution is 
stable over time. (The negative sign on Kakwani indexes for transfers and healthcare use may seem counter-intuitive. The sign is negative because these two concepts are payments to households rather than payments from households. A negative sign indicates that the payments to households are more heavily concentrated in lower-income groups.)

TABLE 2. Gini coefficients, concentration indexes and Kakwani indexes for income and tax payments, British Columbia, 1992 and 2002

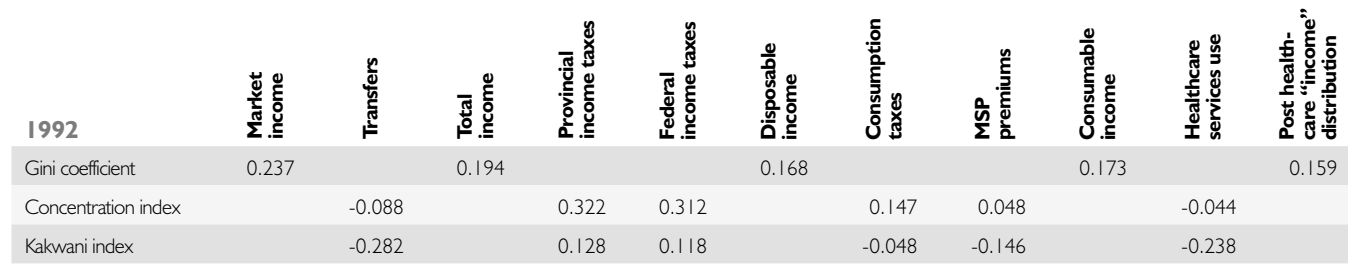

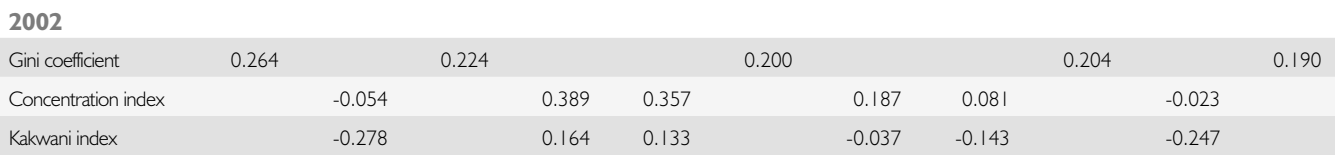

The progressivity of healthcare financing and redistribution of healthcare expenditures

Multiplying the percentage share of government revenue for each type of tax from Table 1 (see online Appendix) by the Kakwani index of progressivity for each from Table 2 and then summing yields an overall tax progressivity index (Table 3). This progressivity lands at about 0.02 in both 1992 and 2002, a figure that is progressive, but only mildly so, and as Table 3 makes clear, is based on calculated Kakwani indexes for only about half of all sources of government revenue.

TABLE 3. Overall progressivity of financing of physician and hospital services in British Columbia, 1992 and 2002

\begin{tabular}{|lcccccc|} 
& $\begin{array}{c}\text { Share of } \\
\text { government } \\
\text { revenues }\end{array}$ & $\begin{array}{c}\text { Kakwani } \\
\text { index of } \\
\text { progressivity }\end{array}$ & $\begin{array}{c}\text { Weighted } \\
\text { contribution }\end{array}$ & $\begin{array}{c}\text { Share of } \\
\text { government } \\
\text { revenues }\end{array}$ & $\begin{array}{c}\text { Kakwani } \\
\text { index of } \\
\text { progressivity }\end{array}$ & $\begin{array}{c}\text { Weighted } \\
\text { contribution }\end{array}$ \\
\hline Provincial income taxes & 0.230 & 0.128 & 0.029 & 0.184 & 0.164 & 0.030 \\
\hline Federal income taxes & 0.062 & 0.118 & 0.007 & 0.058 & 0.133 & 0.008 \\
\hline Consumption taxes & 0.202 & -0.048 & -0.010 & 0.212 & -0.037 & -0.008 \\
\hline Medical services premiums & 0.040 & -0.146 & -0.006 & 0.032 & -0.143 & -0.005 \\
\hline Overall progressivity & & & 0.021 & & & 0.026 \\
\hline
\end{tabular}


Not including Kakwani indexes for the other components of general government revenue is computationally equivalent to saying those taxes are proportionate, that is, that the Kakwanis are equal to 0 . There is clearly a potential for bias in the results, but income taxes are, generally speaking, the only progressive source of tax revenue for governments (Vermaeten et al. 1995; Kesselman and Cheung 2004). All other sources are usually understood to be proportionate at best, except for payments for employment insurance, for which relative contributions follow an inverted $U$-shaped pattern across income groups. The addition of other sources of general government revenue would either leave the results intact, if other financing sources were proportionate, or (more likely) reduce the estimate of progressivity of overall taxation.

FIGURE 3. Tax payments and physician and hospital expenditures as a percentage of income, by income decile, British Columbia, 2002

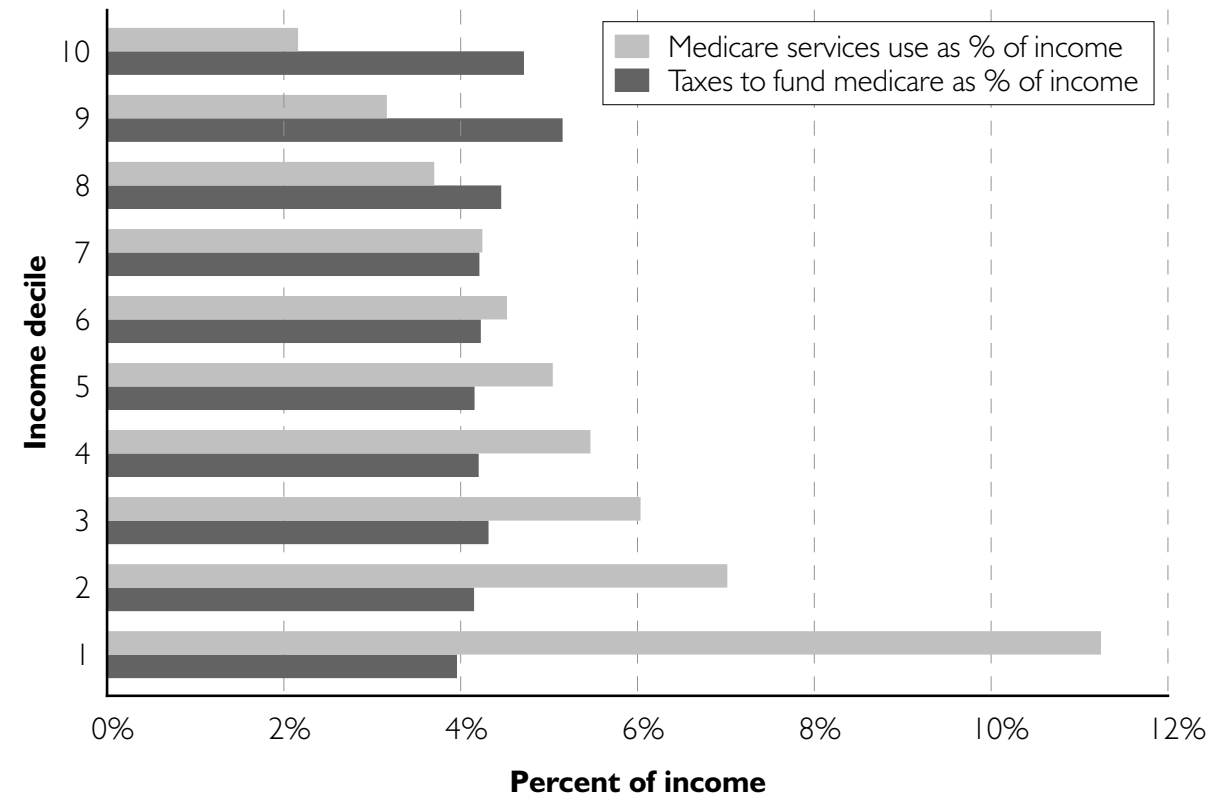

Treating the value of hospital and physician services as a transfer to households has the effect of decreasing income inequality in both years. In both years, income inequality after adding in medicare expenditures is slightly lower than is the inequality of disposable income (Table 2). Figure 3 provides an income decile analysis of this redistribution, showing tax payments and medicare benefits as a percentage of income, with income deciles ranked from lowest (1) to highest (10). As expected, the tax bars indicate roughly equal proportions of income paid in taxes. The medicare bars, how- 
ever, show a marked and consistent increase across deciles, from the use of healthcare services representing about $2 \%$ of total income (on average) in the highest-income group to about $11 \%$ (on average) in the lowest-income group. Part of this trend is a denominator effect, in that the same value of medicare services will represent a higher proportion of income in a lower-income group. Another factor, however, is the inverse correlation between income and need for healthcare services; lower-income groups use more services because they tend to have greater healthcare needs and the healthcare system generally responds to those needs (see, for example, McGrail 2006; van Doorslaer et al. 2006).

\section{Discussion and Conclusions}

There is a strong progressive redistributive effect overall combining the financing and use of physician and hospital services. This effect has been achieved mainly through a policy choice related to the desired redistribution from healthy to sick. A tax-based system of financing creates a complete separation of contributions to financing from the use of physician and hospital services, which means universal contributions and concentrated benefit. The second finance-related policy choice about redistribution across income groups plays a very minor role, with roughly proportionate financial contributions across income groups. In other words, the redistribution occurs because all income groups pay into the system at the same (proportionate) rate, but lowerincome groups use proportionately more healthcare services.

There are several things that must be kept in mind in interpreting this result. First, the analyses are based on distributional information for about half of all sources of general government revenue. The addition of other components of general tax revenues would surely make the finding even closer to proportionate, and perhaps regressive. Second, the use of postal code-derived measures of income and taxes attenuates the amount of inequality and progressivity/regressivity reported. Given the variety of income and tax measures used here, and the fact that they pull in different directions (income inequality will be understated, but so will the progressivity of income taxes), it is difficult to surmise what the overall impact might be. It is possible that they are offsetting effects.

Finally, what is presented here is an estimate of the progressivity of public financing for two sectors of the heathcare system in a single province. If financing for other sectors were added, where the mix of sources is quite different, such as pharmaceuticals and nursing homes and home support services, overall financing for healthcare would certainly be regressive. If analyses were extended to other provinces, there would likely be some differences in the extent of progressivity, especially after 2000 when provincial income tax systems were de-coupled from federal income taxes. Alberta, for example, implemented a proportionate income tax, which would likely 
make overall financing for medicare regressive.

The result of a nearly proportionate overall tax system is consistent with the limited previous Canadian research in this area, at least back to the 1980s (Vermaeten et al. 1995; Dyck 2005; for a detailed review, see Kesselman and Cheung 2004). While proportionate financing for medicare is not inconsistent with the general history of healthcare financing in Canada, it is at odds with the recommendations of the Romanow report. The importance of the Romanow report is that its recommendations came after a concerted effort through the Citizens' Dialogue to understand the priorities of the general public. The general public appears to believe that the healthcare system is financed progressively. The divergence of those beliefs from the current reality deserves some attention in future public policy debates about healthcare financing. A better understanding of financing and distributional issues in general would improve public debate about policy options and their implications.

Correspondence may be directed to: Kimberlyn McGrail, Centre for Health Services and Policy Research, University of British Columbia, 429-2194 Health Sciences Mall, Vancouver, BC V6T 1Z3. Tel: (604) 822-4969. E-mail: kmcgrail@chspr.ubc.ca.

\section{ACKNOWLEDGMENTS}

This work was completed in partial fulfillment of the requirements for a $\mathrm{PhD}$ in the Department of Health Care and Epidemiology at UBC. Comments on earlier versions of these analyses were provided by my thesis committee, Morris Barer, Robert Evans and Clyde Hertzman. I received helpful comments on a draft of this paper from Jennifer Stewart and Allan Maslove. I am also indebted to three anonymous reviewers whose comments led to substantial improvements in the presentation of the material. This research was supported by a CIHR doctoral research award and by the Centre for Health Services and Policy Research at UBC.

\section{REFERENCES}

British Columbia Ministry of Health and Centre for Health Services and Policy Research, UBC. 1996. Access Policy for Research Uses of Linked Health Data. Victoria: Authors.

Canadian Institute for Health Information (CIHI). 2005. National Health Expenditure Trends 1975-2005. Ottawa: Author.

Chamberlayne, R., B. Green, M.L. Barer, C. Hertzman, W.J. Lawrence and S.B. Sheps. 1998. "Creating a Population-Based Linked Health Database: A New Resource for Health Services Research." Canadian Journal of Public Health 89(4): 270-73.

Dyck, D. 2005. “Fiscal Redistribution in Canada, 1994-2000.” Canadian Tax Journal 53(4): 9741006.

Ebert, U. 1997. “Social Welfare When Needs Differ: An Axiomatic Approach.” Economica 64(254): 233-44.

Ebert, U. 1999. “Using Equivalent Income of Equivalent Adults to Rank Income Distributions."

Social Choice and Welfare 16(2): 233-58. 
Frenette, M., D.A. Green and G. Picot. 2004."Rising Income Inequality amid the Economic Recovery of the 1990s: An Exploration of Three Data Sources." Retrieved April 10, 2007. <http://www.econ.ubc.ca/green/ineqnov.pdf>.

Jenkins, S. 1988. “Calculating Income Distribution Indices from Micro-data." National Tax Journal 41(1): 139-42.

Kakwani, N.C. 1977. "Applications of Lorenz Curves in Economic Analysis." Econometrica 45(3): 719-27.

Kakwani, N., A. Wagstaff and E. van Doorslaer. 1997. "Socioeconomic Inequalities in Health: Measurement, Computation, and Statistical Inference." Journal of Econometrics 77(1): 87-103.

Kesselman, J. and R. Cheung. 2004. "Tax Incidence, Progressivity, and Inequality in Canada." Canadian Tax Journal 52(3): 709-67.

Maxwell, J., K. Jackson, B. Legowski, S. Rosell and D. Yankelovich. 2002. Report on Citizens' Dialogue on the Future of Health Care in Canada. Ottawa: Commission on the Future of Health Care in Canada.

McGrail, K.M. 2006. Health, Health Care Services Use and Health Care Financing in British Columbia, 1992 and 2002. Doctoral dissertation, University of British Columbia.

Mendelsohn, M. 2004. Canadians' Thoughts on Their Health Care System: Preserving the Canadian Model through Innovation. Ottawa: Commission on the Future of Health Care in Canada.

Mustard, C.A., M.L. Barer, R.G. Evans, J. Horne, T. Mayer and S. Derksen. 1998. "Paying Taxes and Using Health Care Services: The Distributional Consequences of Tax Financed Universal Health Insurance in a Canadian Province." Conference paper. Retrieved April 10, 2007. <http:// www.csls.ca/events/oct98/must1.pdf>.

Romanow, R.J. 2002. Final Report: Building on Values: The Future of Health Care in Canada. Ottawa: Commission on the Future of Health Care in Canada.

Statistics Canada. 2003. Social Policy Simulation Database and Model. Ottawa: Author. Retrieved April 10, 2007. <http://www.statcan.ca/english/spsd/spsdm.htm>.

Statistics Canada. 2004a. Data Liberation Initiative (DLI). Retrieved April 10, 2007. <http:// www.statcan.ca/english/Dli/dli.htm >.

Statistics Canada. 2004b. Social Policy Simulation Database and Model Commodity Tax User's Guide. Ottawa: Author.

van Doorslaer, E., X. Koolman and A.M. Jones. 2004a. "Explaining Income-Related Inequalities in Doctor Utilisation in Europe." Health Economics 13(7): 629-47.

van Doorslaer, E., C Masseria and OECD Health Equity Research Group Members. 2004b. Income-Related Inequality in the Use of Medical Care in 21 OECD Countries. OECD Health Working Paper No. 14. Paris: Organisation for Economic Co-operation and Development. van Doorslaer, E., C. Masseria, X. Koolman and the OECD Health Equity Research Group. 2006. "Inequalities in Access to Medical Care by Income in Developed Countries." Canadian Medical Association Journal 174(2): 177-83.

Vermaeten, A., W.I. Gillespie and F. Vermaeten. 1995. "Who Paid the Taxes in Canada, 19511988." Canadian Public Policy 21(3): 317-43.

Wagstaff, A., E. van Doorslaer, H. van der Burg, S. Calonge, T. Christiansen, G. Citoni, U.G. Gerdtham, M. Gerfin, L. Gross, U. Hakinnen, P. Johnson, J. John, J. Klavus, C. Lachaud, J. Lauritsen, R. Leu, B. Nolan, E. Peran, J. Pereira, C. Propper, F. Puffer, L. Rochaix, M. Rodriguez, 
M. Schellhorn, G. Sundberg and O. Winkelhake. 1999."Equity in the Finance of Health Care: Some Further International Comparisons." Journal of Health Economics 18(3): 263-90.

Wilkins, R. 2001. PCCF+ Version 3G User's Guide (Geocodes/PCCF): Automated Geographic Coding Based on the Statistics Canada Postal Code Conversion Files Including Postal Codes to June 2001. Ottawa: Statistics Canada. Retrieved February 17, 2004. <http://data.library.ubc.ca/ datalib/survey/statscan/census/1996/health2001/pccf3g.pdf $>$.

\section{Over 1.2 million hits a month} See what you're missing 


\section{Medicare Financing and Redistribution in British Columbia, 1992 and 2002}

KIMBERLYN MCGRAIL

Appendix

TABLE 1. Consolidated provincial government revenue and expenditures for fiscal year ending March 31, British Columbia, 1989-2003

\begin{tabular}{|c|c|c|c|c|c|c|c|c|c|c|c|c|c|}
\hline Dollar Amounts & 1992 & 1993 & 1994 & 1995 & 1996 & 1997 & 1998 & 1999 & 2000 & 2001 & 2002 & 2003 & 2004 \\
\hline Total revenue & 18,664 & 20,237 & 22,807 & 24,682 & 25,411 & 25,689 & 26,843 & 26.129 & 27.877 & 30,216 & 29,730 & 29,101 & 30,999 \\
\hline Oun source revenve & 16,334 & 17,452 & 20,257 & 21,934 & 22,807 & 23.519 & 24,676 & 23,594 & 24,745 & 26.907 & 26,253 & 24,877 & 26.811 \\
\hline Income taxes & 4.851 & 4.588 & 5.676 & 5,883 & 6.489 & 6.764 & 6.600 & 6,616 & 7,016 & 7.369 & 7,188 & 5,029 & 5.922 \\
\hline Persanal income taxes & 4.295 & 4.026 & 4.916 & 4,767 & 5.064 & 5.337 & 5.406 & 5,469 & 5.990 & 6.148 & 5.481 & 4,262 & 4.993 \\
\hline Consumption taxes & 3.771 & 4.042 & 4.756 & 5.095 & 5.219 & 5.354 & 5.600 & 5.708 & 6.002 & 6.322 & 6.290 & 6.763 & 7.244 \\
\hline Property and related taxes & 1,304 & 1,799 & 2,015 & 2.010 & 1.953 & 2.037 & 2.079 & 2.079 & 2,122 & 2.161 & 2.169 & 2,133 & 2,203 \\
\hline Other taxes & 461 & 466 & 519 & 564 & 582 & 554 & 609 & 590 & 585 & 591 & 600 & 632 & 666 \\
\hline $\begin{array}{l}\text { Heath and drug insurance } \\
\text { premiums }\end{array}$ & 742 & 777 & 779 & 805 & 822 & 853 & 881 & 876 & 868 & 895 & 955 & 1,358 & 1,387 \\
\hline $\begin{array}{l}\text { Contributions to social } \\
\text { security plans }\end{array}$ & 594 & 650 & 735 & 885 & 990 & 1,039 & 980 & 912 & 874 & 866 & 920 & 994 & 1.025 \\
\hline Sales of goods and services & 1.421 & 1.423 & 1,573 & 1.681 & 1.870 & 1.831 & 2,133 & 2,119 & 2,242 & 2,357 & 2,526 & 2,838 & 2,846 \\
\hline Investment income & 2,845 & 3,396 & 3.987 & 4,712 & 4,685 & 5.075 & 5.244 & 4,062 & 4,676 & 6.075 & 4.922 & 4,741 & 5,065 \\
\hline $\begin{array}{l}\text { Other revenues from own } \\
\text { sources }\end{array}$ & 347 & 312 & 218 & 301 & 195 & 13 & 545 & 628 & 361 & 271 & 688 & 987 & 851 \\
\hline $\begin{array}{l}\text { General purpose tranders } \\
\text { from other governments }\end{array}$ & 16 & 44 & 42 & 65 & 14 & 1.785 & 1,685 & 2.008 & 2,495 & 2,632 & 2,737 & 3.417 & 2,737 \\
\hline $\begin{array}{l}\text { Speofic purpose transfers } \\
\text { from other governments }\end{array}$ & 2.314 & 2.742 & 2.507 & 2.683 & 2.590 & 385 & 482 & 526 & 637 & 677 & 725 & 765 & 1,213 \\
\hline
\end{tabular}

\begin{tabular}{|c|c|c|c|c|c|c|c|c|c|c|c|c|c|}
\hline & 875 & & & ת & & (1) & & & & & & & \\
\hline Income taxes & 260 & & & & & & & & & & & & \\
\hline & & & & & & & & & & & & & \\
\hline Persond income toves & 23.0 & 19.9 & 21.6 & 19.3 & 19.9 & 20.8 & 20.1 & 20.9 & 21.5 & 20.3 & 18.4 & 14.6 & 16.1 \\
\hline Consumption taxes & 20.2 & 20.0 & 20.9 & 20.6 & 20.5 & 20.8 & 20.9 & 21.8 & 21.5 & 20.9 & 21.2 & 23.2 & 23.4 \\
\hline Property and related taxes & 7.0 & 8.9 & 8.8 & 8.1 & 7.7 & 7.9 & 7.7 & 8.0 & 7.6 & 7.2 & 7.3 & 7.3 & 7.1 \\
\hline Other taxes & 2.5 & 2.3 & 2.3 & 2.3 & 2.3 & 2.2 & 2.3 & 2.3 & 2.1 & 2.0 & 2.0 & 2.2 & 2.1 \\
\hline $\begin{array}{l}\text { Heath and dnug insurance } \\
\text { premiums }\end{array}$ & 4.0 & 3.8 & 3.4 & 3.3 & 3.2 & 3.3 & 3.3 & 3.4 & 3.1 & 3.0 & 3.2 & 4.7 & 4.5 \\
\hline $\begin{array}{l}\text { Contributions to social } \\
\text { searity plans }\end{array}$ & 3.2 & 3.2 & 3.2 & 3.6 & 3.9 & 4.0 & 3.7 & 3.5 & 3.1 & 2.9 & 3.1 & 3.4 & 3.3 \\
\hline Sales of goods and services & 7.6 & 7.0 & 6.9 & 6.8 & 7.4 & 7.1 & 7.9 & 8.1 & 8.0 & 7.8 & 8.5 & 9.8 & 9.2 \\
\hline Investment income & 15.2 & 16.8 & 17.5 & 19.1 & 18.4 & 19.8 & 19.5 & 15.5 & 16.8 & 20.1 & 16.6 & 16.3 & 16.3 \\
\hline $\begin{array}{l}\text { Other revenues from own } \\
\text { sources }\end{array}$ & 1.9 & 1.5 & 1.0 & 1.2 & 0.8 & 0.1 & 2.0 & 2.4 & 1.3 & 0.9 & 2.3 & 3.4 & 2.7 \\
\hline $\begin{array}{l}\text { General purpose transers } \\
\text { from other govermments }\end{array}$ & 0.1 & 0.2 & 0.2 & 0.3 & 0.1 & 6.9 & 6.3 & 7.7 & 9.0 & 8.7 & 9.2 & 11.7 & 8.8 \\
\hline $\begin{array}{l}\text { Speodic purpose transfers } \\
\text { from other governments }\end{array}$ & 12.4 & 13.5 & 11.0 & 10.9 & 10.2 & 1.5 & 1.8 & 2.0 & 2.3 & 2.2 & 2.4 & 2.6 & 3.9 \\
\hline
\end{tabular}

Source: CANSIM 385000I. "Consolidated Provincial Govemment Revenue And Expenditure, For Fiscal Year Ending March 31" 
TABLE 4. Estimates of household-level consumption taxes, as derived from the Social Policy Simulation Database and Model

\begin{tabular}{lll} 
Income group & $\mathbf{1 9 9 2}$ & $\mathbf{2 0 0 2}$ \\
\hline $0-\$ 5,000$ & 1,062 & 1,667 \\
$\$ 5,001-\$ 10,000$ & 1,200 & 1,238 \\
$\$ 10,001-\$ 15,000$ & 1,657 & 1,842 \\
$\$ 15,001-\$ 20,000$ & 2,814 & 2,361 \\
$\$ 20,001-\$ 25,000$ & 2,831 & 2,797 \\
\hline$\$ 25,001-\$ 30,000$ & 3,362 & 3,494 \\
$\$ 30,001-\$ 35,000$ & 3,613 & 4,131 \\
$\$ 35,001-\$ 40,000$ & 3,875 & 4,230 \\
\hline$\$ 40,001-\$ 50,000$ & 4,885 & 4,874 \\
\hline$\$ 50,000$ & 7,821 & 8,558 \\
\hline Population average & 3,439 & 4,261 \\
\hline
\end{tabular}

TABLE 5. BC premium rates and income-based subsidy cut-points, 1992

\begin{tabular}{lccccccc|} 
& \multicolumn{2}{c}{ Monthly premium $\mathbf{( \$ )}$ by family size } & \multicolumn{3}{c}{ Yearty premium (\$) by family size } \\
\hline Income group & $\mathbf{1}$ & $\mathbf{2}$ & $\mathbf{3 +}$ & $\mathbf{1}$ & $\mathbf{2}$ & $\mathbf{3 +}$ \\
\hline $0-\$ 9.000$ & 1.75 & 3.10 & 3.50 & 21.00 & 37.20 & 42.00 \\
\hline$\$ 9.000 .01-\$ 11,000$ & 8.75 & 15.50 & 17.50 & 105.00 & 186.00 & 210.00 \\
\hline$\$ 11,000.01-\$ 13,000$ & 15.75 & 27.90 & 31.50 & 189.00 & 334.80 & 378.00 \\
\hline$\$ 13,000.01-\$ 15.000$ & 22.75 & 44.30 & 45.50 & 273.00 & 531.60 & 546.00 \\
$\$ 15.000 .01-\$ 17,000$ & 29.75 & 52.70 & 59.50 & 357.00 & 632.40 & 714.00 \\
$\$ \$ 17.000 .01$ and over & 35.00 & 62.00 & 70.00 & 420.00 & 744.00 & 840.00
\end{tabular}

TABLE 6. BC premium rates and income-based subsidy cut-points, 2002

\begin{tabular}{|c|c|c|c|c|c|c|c|c|c|}
\hline \multirow[b]{2}{*}{ Income group } & \multicolumn{3}{|c|}{$\begin{array}{l}\text { Monthly premium (\$) by } \\
\text { family size to Apr. } 30\end{array}$} & \multicolumn{3}{|c|}{$\begin{array}{l}\text { Monthly premium (\$) by } \\
\text { family size starting May I }\end{array}$} & \multicolumn{3}{|c|}{$\begin{array}{c}\text { Yearly premium (\$) } \\
\text { by family size }\end{array}$} \\
\hline & 1 & 2 & $3+$ & 1 & 2 & $3+$ & 1 & 2 & $3+$ \\
\hline$\$ 12,000.01-\$ 14,000$ & 7.20 & 12.80 & 14.40 & 0.00 & 0.00 & 0.00 & 28.80 & 51.20 & 57.60 \\
\hline$\$ 14,000.01-\$ 16.000$ & 14.40 & 25.60 & 28.80 & 0.00 & 0.00 & 0.00 & 57.60 & 102.40 & 115.20 \\
\hline$\$ 16.000 .01-\$ 18.000$ & 21.60 & 38.40 & 43.20 & 10.80 & 19.20 & 21.60 & 172.80 & 307.20 & 345.60 \\
\hline$\$ 18,000.01-\$ 20,000$ & 28.80 & 51.20 & 57.60 & 21.60 & 38.40 & 43.20 & 288.00 & 512.00 & 576.00 \\
\hline$\$ 20,000.01-\$ 22.000$ & 36.00 & 64.00 & 72.00 & 32.40 & 57.60 & 64.80 & 403.20 & 716.80 & 806.40 \\
\hline$\$ 22,000.01-\$ 24,000$ & 36.00 & 64.00 & 72.00 & 43.20 & 76.80 & 86.40 & 489.60 & 870.40 & 979.20 \\
\hline$\$ 24,000.01$ and over & 36.00 & 64.00 & 72.00 & 54.00 & 96.00 & 108.00 & 576.00 & 1024.00 & 1152.00 \\
\hline
\end{tabular}

